\title{
Rearrangement of chromatin domains during development in Xenopus
}

\author{
Yegor Vassetzky, ${ }^{1}$ Alan Hair, ${ }^{1,2}$ and Marcel Méchali ${ }^{3}$ \\ Institut de Génétique Humaine, Genome Dynamics and Development, Centre National de Recherche Scientifique (CNRS), \\ 34396 Montpellier Cedex 5, France
}

\begin{abstract}
A dynamic change in the organization of different gene domains transcribed by RNA polymerase I, II, or III occurs during the progression from quiescent [pre-midblastula transition (pre-MBT)] to active (post-MBT) embryos during Xenopus development. In the rDNA, c-myc, and somatic $5 \mathrm{~S}$ gene domains, a transition from random to specific anchorage to the nuclear matrix occurs when chromatin domains become active. The keratin gene domain was also randomly associated to the nuclear matrix before MBT, whereas a defined attachment site was found in keratinocytes. In agreement with this specification, ligation-mediated (LM)-PCR genomic footprinting carried out on the subpopulation of $5 \mathrm{~S}$ domains specifically attached to the matrix reveals the hallmarks of determined chromatin after the midblastula transition. In contrast, the same analysis performed on the total $5 \mathrm{~S}$ gene population does not reveal specific chromatin organization, validating the use of nuclear matrix fractionation to unveil active chromatin domains. These data provide a means for the determination of active chromosomal territories in the embryo and emphasize the role of nuclear architecture in regulated gene expression during development.
\end{abstract}

[Key Words: Xenopus; nuclear matrix; genomic organization; transcription]

Received February 16, 2000; revised version accepted April 18, 2000.

The extensive characterization of genes and proteins that regulate gene expression through interaction with DNA has permitted the understanding of how a transcription complex is built and revealed the role of chromatin as an essential part of gene regulation. Several independent approaches have also revealed the dynamic aspect of this regulation and allowed the re-emergence and re-analysis of the role of nuclear architecture on gene expression (for review, see Vermaak and Wolffe 1998). One level of nuclear architecture that contributes to this regulation is an underlying nonhistone nucleoprotein structure called scaffold, or the nuclear matrix (Berezney and Coffey 1975; Paulson and Laemmli 1977; Cockerill and Garrard 1986). Active replication and transcription sites have been observed clustered in this nuclear structure which delimits spatially and temporally defined territories in the nucleus (for review, see Laemmli et al. 1992; Berezney et al. 1995).

This underlying nuclear organization is not thoroughly characterized at the biochemical level, but DNA elements called scaffold or matrix-associated regions (SARs or MARs) that permit the attachment of the DNA loop domains to the matrix have been defined (Paulson and Laemmli 1977; Vogelstein et al. 1980; Mirkovitch et

\footnotetext{
${ }^{1}$ These authors contributed equally to this work.

${ }^{2}$ Present address: Gene Expression Group, School of Biological Sciences, The University of Manchester, Manchester M13 9PT UK. ${ }^{3}$ Corresponding author.

E-MAIL mechali@igh.cnrs.fr; FAX 33-(0) 499619920.
}

al. 1984). These elements are frequently associated with enhancer elements (Gasser and Laemmli 1986) and can increase the activity of those enhancer elements. They can also protect genes from position effects by acting as boundary elements (Grosveld et al. 1987; Jarman and Higgs 1988; Scheuermann and Chen 1989; Stief et al. 1989; Forrester et al. 1994; Zong and Scheuermann 1995; Jenuwein et al. 1997).

An unresolved issue at this time is whether the distribution of attachment sites is stable or may change in relation to specific programs of transcription during development. SARs associated with enhancer elements of three developmentally regulated genes in Drosophila were found in both embryonic and adult cells (Gasser and Laemmli 1986), and in the hsp70 heat-shock gene cluster the same attachment sites were found in both control and heat-shocked Drosophila cells (Mirkovitch et al. 1984). Xenopus development provides an interesting model for testing transitions in gene expression during development that could be associated with a change in the organization of genomic domains. During twelve divisions after fertilization, the embryonic genome is transcriptionally quiescent. The onset of transcription occurs at the thirteenth cell cycle and defines the midblastula transition or MBT (Newport and Kirschner 1982).

Here, we investigated whether activation of zygotic transcription after the MBT was structurally associated to the specification of nuclear matrix attachment regions in three specific gene domains, $r D N A, \mathrm{c}-m y c$, and $5 \mathrm{~S}$. 
The rDNA gene cluster is composed of 400 tandemly repeated highly conserved genes separated by intergenic spacers rich in promoter and enhancer elements and is transcribed by RNA polymerase I. Its transcription starts at the gastrula stage (Shiokawa et al. 1981). The c-myc locus consists of a $2.5-\mathrm{kb}$ region that is transcribed by RNA polymerase II. The somatic 5S RNA is encoded by a multicopy gene transcribed by RNA polymerase III. Both of these genes are activated after the MBT (Taylor et al. 1986; Wolffe and Brown 1988). In these three domains, we show that a specific attachment to the matrix is achieved when embryos become transcriptionally active. In contrast, the $63-\mathrm{kD}$ keratin gene domain, which is transcribed only in adult keratinocytes (Nishikawa et al. 1992), is not specified at the MBT. Ligation-mediated (LM)-PCR genomic footprinting was also used to analyze the determination of the $5 \mathrm{~S}$ domain and its relationship to the attachment to the nuclear matrix during development. When the whole population of somatic $5 \mathrm{~S}$ genes was studied, we could not detect a clear footprint both in pre- or post-MBT embryos. However, nuclear matrix fractionation coupled with LM-PCR footprinting permitted the organization of the transcriptionally active $5 \mathrm{~S}$ domain in post-MBT embryos to be revealed. These observations confirm the restriction of the nuclear matrix sites when transcription resumes in the embryo. They also point to the importance of the nuclear structure in the establishment of transcription complexes during development. In addition, nuclear matrix fractionation appears to be a useful option to distinguish active chromatin domains in nonhomogeneous gene populations.

\section{Results}

\section{Specification of matrix attachment sites during} Xenopus development

Isolation of nuclear matrix in a low-salt buffer using lithium-3-5-diiodosalicylate (LIS method) has allowed isolation and mapping of the DNA regions that structurally define the base of the loop domains, the scaffold attachment sites (Mirkovitch et al. 1984; Gasser and Laemmli 1986). LIS can remove histones and nonhistone proteins but maintains the interactions of SARs with the resulting nuclear scaffold. We used this method to isolate the nuclear matrix after a DNase I treatment to detach the DNA loops from the matrix (Fig. 1A; see Material and Methods). The DNA remaining on the matrix was radiolabeled and used as a probe to examine the specification of the nuclear matrix attachment sites of two gene domains, rDNA and c-myc, which are activated after the MBT. The keratin domain, containing the $63-\mathrm{kD}$ keratin gene, which is not activated after the MBT but activated in adult keratinocytes, was also analyzed here.

Each unit of the rDNA domain comprises a transcribed region and a nontranscribed spacer. A recombinant plasmid containing the rDNA unit was digested with EcoRI, XbaI, and HindIII to produce fragments representing different regions of the rDNA gene. These were then separated on agarose gel (Fig. 1B,C). The gels were
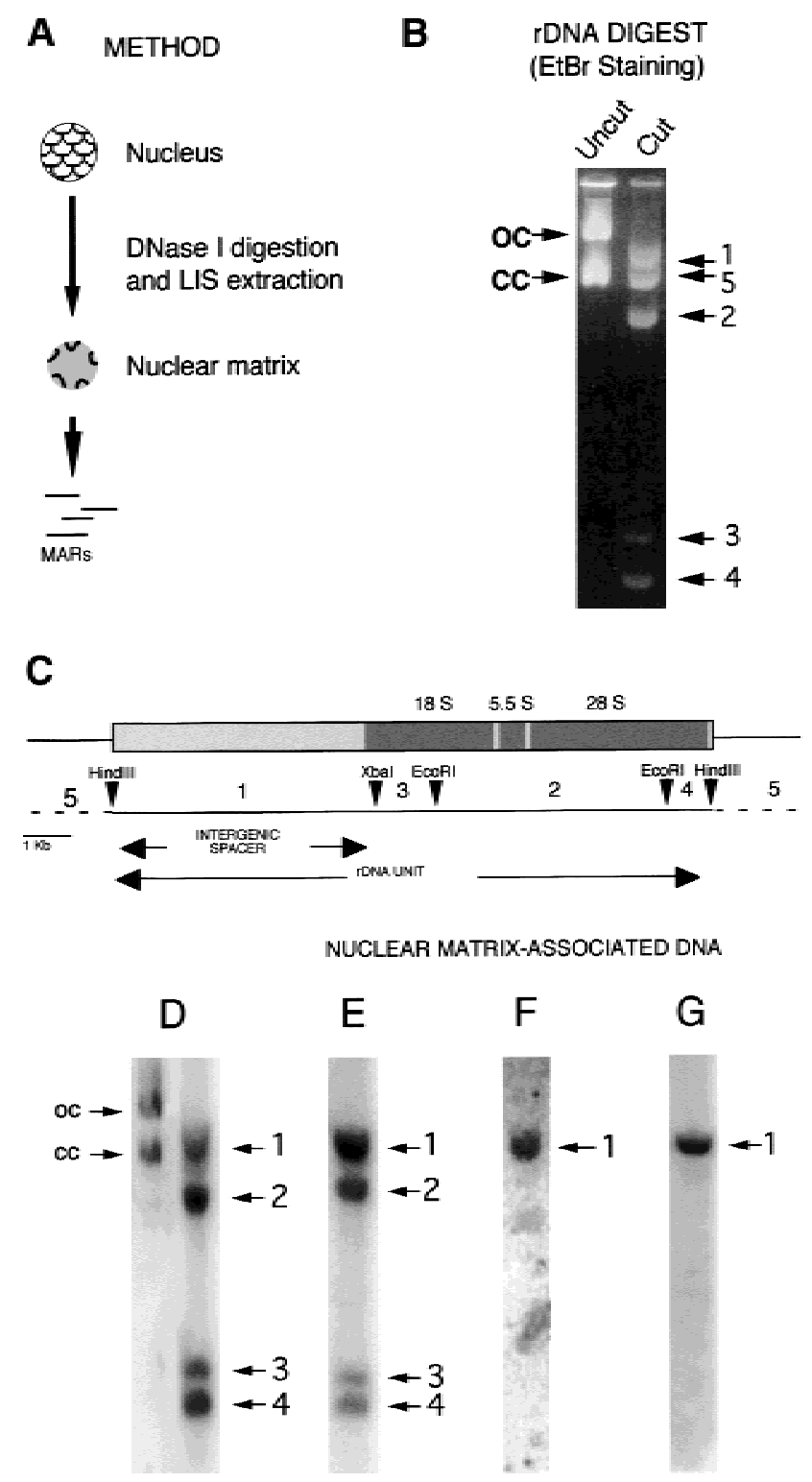

Figure 1. Specification of the nuclear matrix attachment sites in the rDNA domain during development. $(A)$ Nuclei from preMBT embryos, gastrula embryos, or adult liver cells were isolated and treated by DNase I. The nuclear matrix was then prepared using LIS extraction (see Material and Methods) and the DNA fragments remaining on the matrix were radiolabeled to probe for specific regions in the rDNA domain shown in $C$. The DNA fraction remaining attached to the nuclear matrix is $5 \%, 3.5 \%$, and $2 \%$ in lanes $E, F$, and $G$, respectively. (B) A plasmid containing the Xenopus rDNA domain was cut with HindIII, EcoRI, and $\mathrm{XbaI}$ to produce five distinct fragments after migration on agarose gel. $(C)$ Map of the rDNA domain inserted in the plasmid. Fragments 1-4 overlap the rDNA domain and fragment 5 is the DNA vector. $(D-G)$ The plasmid was digested $(B)$ and was hybridized either with total $\operatorname{rDNA}(D$, uncut and cut plasmid are in left and right lanes), or with the DNA attached to the nuclear matrix of early embryos $(E)$, gastrula embryos $(F)$, or liver cell nuclei $(G)$. 
probed with either total Xenopus DNA (Fig. 1D) or matrix DNA (Fig. 1E-G). Embryos taken before the onset of transcription (2000-cell pre-MBT embryos) or after the onset of transcription (post-MBT embryos), as well as adult liver tissues, were examined.

Figure 1E shows that the matrix-associated DNA from pre-MBT embryos hybridizes to all the rDNA fragments, as with total Xenopus DNA (Fig. 1D), indicating that the association of DNA to the nuclear matrix was random during early development. In contrast, after the MBT (stage 10), the association of the rDNA domain with the nuclear matrix becomes specific, restricted to the intergenic spacer region (Fig. 1F). The same specificity was observed in nuclei from differentiated adult liver cells (Fig. 1G). We conclude from this that a reorganization of the rDNA domain in the nucleus occurs during Xenopus development. This domain appears randomly attached to the nuclear matrix during early development, when transcription is repressed in the embryo. The specification of the nuclear matrix attachment site occurs after the midblastula stage, when transcription commences in the embryo.

To determine whether this phenomenon was particular to multicopy genes or could be confirmed for singlecopy genes transcribed by the RNA polymerase II machinery, the organization of the c-myc gene domain was also analyzed. c-myc transcription is dependent on the presence of a TATA box element and is activated in a constitutive manner after MBT (King et al. 1986; Taylor et al. 1986). A 12-kb domain encompassing the 3.5-kb c-myc DNA transcribed region was analyzed in Figure 2A. Two different restriction cuts of a plasmid containing this domain were used to scan the whole domain using the DNA remaining attached to the nuclear matrix as a probe. In pre-MBT embryos, both the $5^{\prime}$ and $3^{\prime}$ regions flanking the coding sequence were detected in the nuclear matrix fraction (Fig. 2A, c), with a preferential attachment site located between -3400 and -1300 from the c-myc P2 promoter. In post-MBT embryos, a restriction of the attachment sites occurs mainly in the 5' upstream region of c-myc (Fig. 2A, d). In adult liver tissues, a single region corresponding to the prominent matrix attachment site $5^{\prime}$ upstream of $\mathrm{c}-m y c$ remained (Fig. 2A, e).

We conclude that as for the rDNA domain, a restriction of the c-myc attachment sites occurs during embryogenesis. For this single-copy gene, the coding sequence is already excluded from the nuclear matrix before MBT, and the 1100-bp attachment region upstream of c-myc becomes the prominent nuclear matrix site as development progresses.

Both studied domains contain genes that are activated relatively early in embryogenesis. The $63-\mathrm{kD}$ keratin gene, which is transcribed at a much later time, in adult keratinocytes (Nishikawa et al. 1992; Warshawsky and Miller 1995; Warshawsky and Miller 1997) was also analyzed. A 14-kb domain encompassing the keratin gene was cloned from a Xenopus genomic library and analyzed in pre- and post-MBT embryos, as well as in adult keratinocytes (Fig. 2B). In contrast to the rDNA gene domain and the c-myc domain, no specification of nuclear matrix attachment sites was detected in pre- or post-MBT embryos (Fig. 2B, cd). However, in adult keratinocytes the attachment of the keratin domain to the nuclear matrix becomes specific and circumscribed to a 3.5-kb DNA region located $\sim 7 \mathrm{~kb}$ upstream from the transcription start (Fig. 2B, e). We conclude that the rearrangement that occurs at the nuclear matrix level is not a general feature of all genes at the MBT but may be related to the timing of their expression in the embryo.

Chromosomal footprinting of the whole population of $5 S$ somatic gene before or after the MBT does not reveal substantial chromatin modification

The determination of the nuclear MARs after the MBT correlated with the activation of transcriptional programs in the embryo. These changes may be due to the association of transcription factors or to a presetting of chromatin domains for their expression. Before MBT, when transcription is repressed, the presence of a store of adequate transcription factors can nevertheless program reporter genes injected in the fertilized egg (Prioleau et al. 1994, 1995; Almouzni and Wolffe 1995). In order to analyze whether endogenous chromatin itself could already be programmed before $\mathrm{MBT}$, we chose the somatic ribosomal $5 \mathrm{~S}$ gene whose transcriptional activation after the MBT depends on a transcriptional activator, TFIIIA, already present in the fertilized egg. This small gene belongs to class III transcribed genes, is present in 400 copies per haploid genome, and is rapidly transcribed at the MBT (Newport and Kirschner 1982). Its promoter has been extensively characterized, and TFIIIA is already present, potentially active, in large excess in the egg (for review, see Pieler and Theunissen 1993; Wolffe 1994).

We compared the chromatin at the endogenous somatic 5S RNA locus in pre- and post-MBT embryos using genomic footprinting by DNase I and LM-PCR, which permits the examination of the locus at the nucleotide level. To analyze the somatic $5 \mathrm{~S}$ region on both DNA strands, two sets of primers were designed that allow the amplification of DNA fragments generated by DNase I digestion, reading from the $3^{\prime}$ linker sequence, through the transcription unit and out into the 5' linker sequence (S4, S5, and S6; Material and Methods), and also in the opposite direction, that is, from the 5 ' linker sequence, through the transcription unit and into the $3^{\prime}$ linker sequence (S1, S2, and S3). The overlap of the sequences analyzed by the primer sets allowed confirmation of the sequence being examined.

Using different levels of DNase I, we never observed clear patterns of protection along the gene (Fig. 3; data not shown). Several hypersensitive sites were observed in pre-MBT embryos, mainly localized in the $3^{\prime}$ region of the gene, which contains the internal control region. The post-MBT chromatin appeared less accessible, and the preference for hypersensitive sites had moved to the 5' region of the gene in the coding strand. The increased accessibility of the somatic $5 S$ domain in pre-MBT embryos may be due to a general phenomenon affecting 
Figure 2. Specification of the nuclear matrix site in the c-myc and keratin domains during development. (A) c-myc domain. Nuclei from pre-MBT gastrula embryos or adult liver cells were treated as described in Fig. 1A. The DNA remaining attached to the nuclear matrix was radiolabeled to probe for specific regions in the c-myc genomic domain. A plasmid containing 12 $\mathrm{kb}$ of c-myc DNA was cut with HindIII and EcoRI, or PvuII to give the restriction map shown in $a$. The position of the transcribed c-myc domain is shown, as well as the initiation site $\mathrm{P} 2$, from which c-myc is transcribed in Xenopus (Taylor et al. 1986; Prioleau et al. 1995). The fragments of the c-myc plasmid were separated by agarose gel electrophoresis $(b)$ and hybridized with the nuclear matrix associated DNA from early embryos $(c)$, gastrula embryos $(d)$, or liver cell nuclei $(e)$. (B) Keratin domain. Nuclei from pre-MBT, gastrula, and tailbud stage embryos or adult keratinocytes were treated as described in Fig. 1A. The DNA remaining attached to the nuclear matrix was radiolabeled to probe for specific regions in the keratin genomic domain. An EMBL3 phage containing a 14-kb domain encompassing the keratin gene was cut with HindIII/EcoRI, to give the restriction map shown in $a$. The position of the transcribed keratin gene is shown (L. Miller, pers. comm.). The fragments of the keratin domain were separated by agarose gel electrophoresis $(b)$ and hybridized with the nuclear matrix associated DNA from early embryos $(c)$, gastrula embryos $(d)$, or adult keratinocyte nuclei $(e)$.

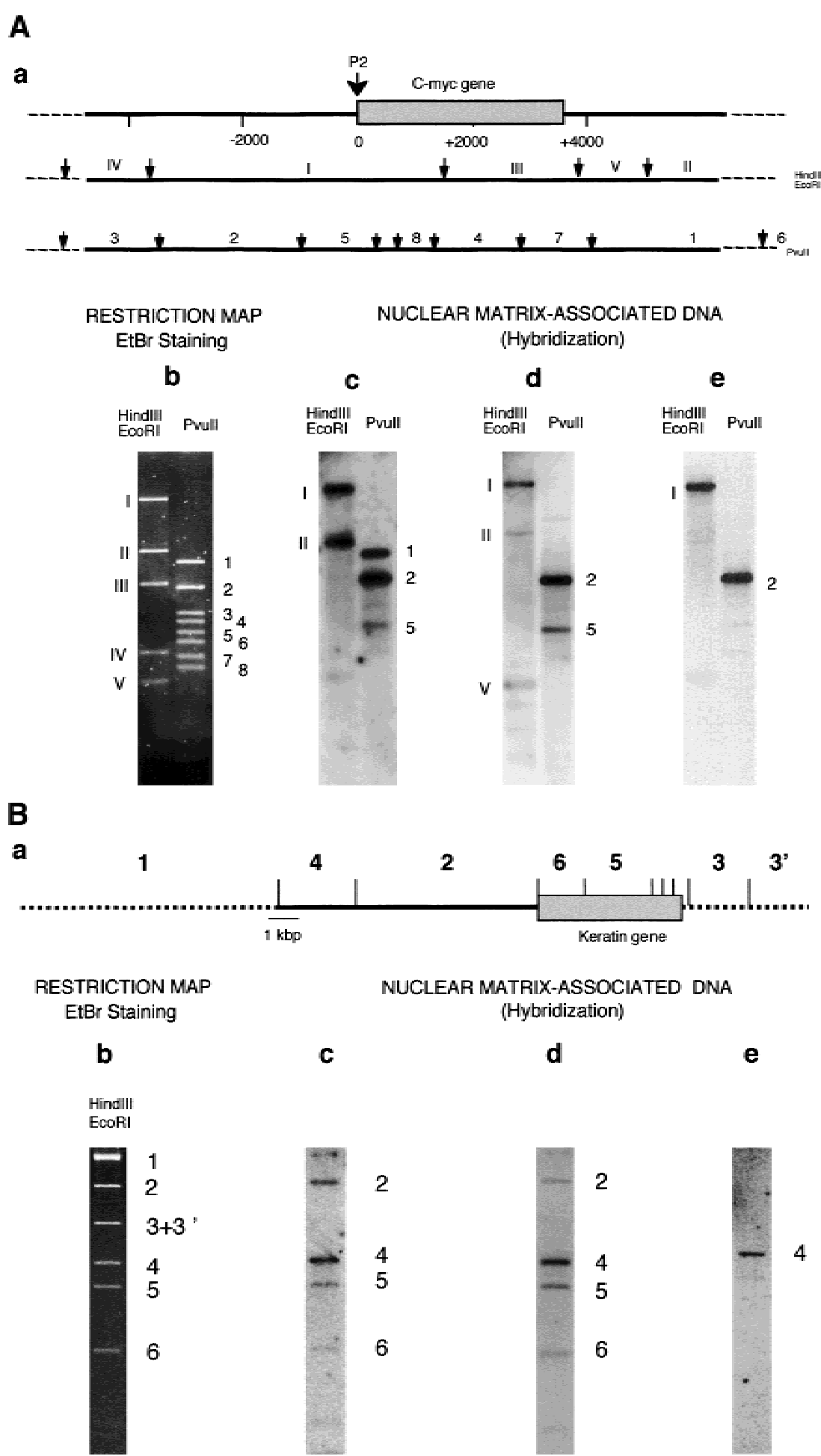

bulk chromatin being less condensed than in post-MBT embryos. Considering the high level of transcription of the somatic $5 \mathrm{~S}$ gene post-MBT, it was surprising that no protection of the gene region and no hallmarks of transcription factor binding were observed, as, for example, in the region bound by TFIIIA on in vitro-reconstituted DNA-TFIIIA complexes (for review, see Pieler and Theunissen 1993).
Genomic footprinting associated with nuclear matrix isolation reveals the chromatin organization and the boundaries of the somatic $5 S$ gene in post-MBT embryos

A likely explanation for the failure to observe a clear footprint on the $5 \mathrm{~S}$ somatic gene was that only a fraction of the gene copies were being expressed and therefore the 


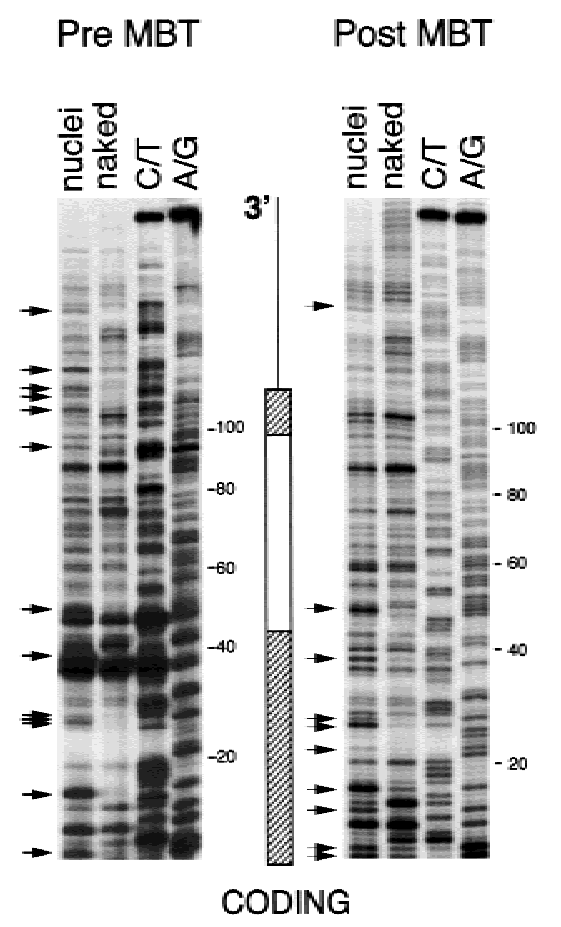

\section{Pre MBT}

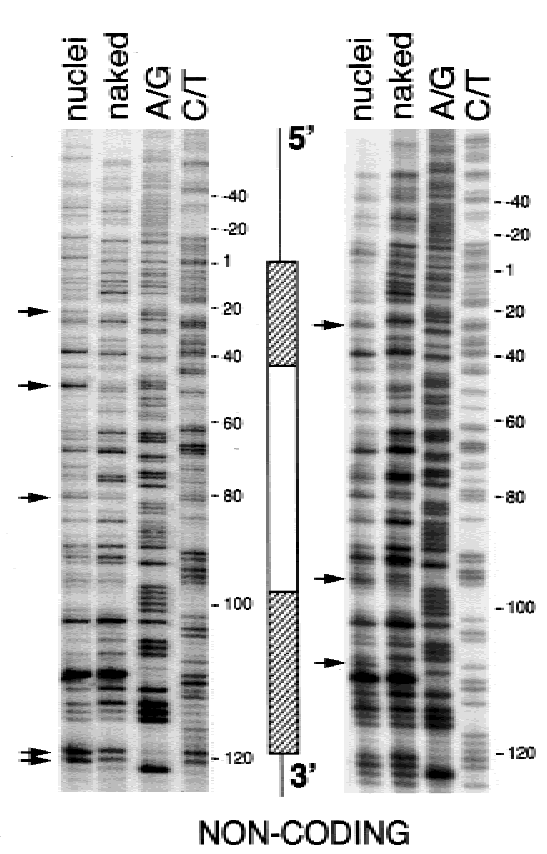

Figure 3. Genomic footprinting of the somatic $5 \mathrm{~S}$ gene in pre- and post-MBT embryos. Embryonic nuclei were isolated from inactive (pre-MBT) or active embryos (stage $10)$ and treated for DNase I genomic footprinting as described in Material and Methods. Both the coding strand and the noncoding strand were analyzed. Nuclei refer to the DNase I genomic footprint, naked is purified DNA treated by DNase I, and C/T and A/G were sequencing lanes. The somatic $5 \mathrm{~S}$ map is shown with the coding sequence (grey box) including the internal control region (white box). DNase I hypersensitive sites are indicated. Arrows mark hypersensitive sites reproducibly observed in post-MBT embryos. occupancy of the internal promoter could have been masked in an average pattern of all the gene copies. A similar possibility was mentioned for the lack of the expected TFIIIA footprint on the promoter of the oocyte type 5S gene expressed in the oocyte (Engelke et al. 1980). Nuclear matrix isolated by the classic $\mathrm{NaCl}$ method was found in association with actively transcribed genes in several independent studies (for review, see Berezney et al. 1995; Stein et al. 1995; Jackson 1997). The specification of the nuclear matrix sites that we observed during development led to consider that chromatin domains attached to the matrix could be enriched in transcriptionally active chromatin. A related approach using nuclear matrix fractionation allowed the enrichment of replicating DNA and were found essential to reveal origins of DNA replication in eukaryotes (Dijkwel et al. 1991).

We analyzed the portion of somatic $5 \mathrm{~S}$ copies that were attached to the nuclear matrix by treating the embryonic nuclei with HindIII, which excises the somatic $5 \mathrm{~S}$ units. Using slot blot hybridizations and agarose gel electrophoresis, we measured that $23 \%$ of the $5 \mathrm{~S}$ units were attached to the matrix in post-MBT embryos /data not shown). To test whether the nuclear matrix fraction contained active $5 \mathrm{~S}$ genes, we analyzed the distribution of the nascent 5S RNA transcripts in the salt-extracted nuclear matrix and the nonmatrix fractions. Nuclei were isolated from stage 13 embryos, and a run-on transcription was carried out in the presence of $\left[\alpha-{ }^{32} \mathrm{P}\right] \mathrm{UTP}$ as described in (Verheggen et al. 1998). The nuclear matrix and the soluble fractions were isolated, and the RNA extracted from both fractions was used as a probe to hybridize with the 5S RNA gene. Figure 4 shows that most of the nascent 5S RNA transcripts were in the nuclear matrix fraction, indicating that the active $5 \mathrm{~S}$ gene units were associated to this fraction.

The specification of the $5 \mathrm{~S}$ nuclear matrix attachment sites was analyzed in Figure 5A,B. A 324-bp region (BanII, fragment 5) encompassing the internal control region of the somatic $5 \mathrm{~S}$ gene was detected in the nuclear matrix fraction of DNase I treated nuclei from post-MBT embryos. In contrast, no specific attachment was detected before MBT. We have also used an alternative method, based on DNase I digestion of agarose-embedded nuclei (Jackson and Cook 1985). The nucleoskeleton was separated from cleaved-off DNA by DNA electrophoresis, and the nucleoskeleton-associated DNA was isolated and used as probe to map the attachment points (Fig. 5B, e). These two different methods produced similar results; the same DNA region found associated to the

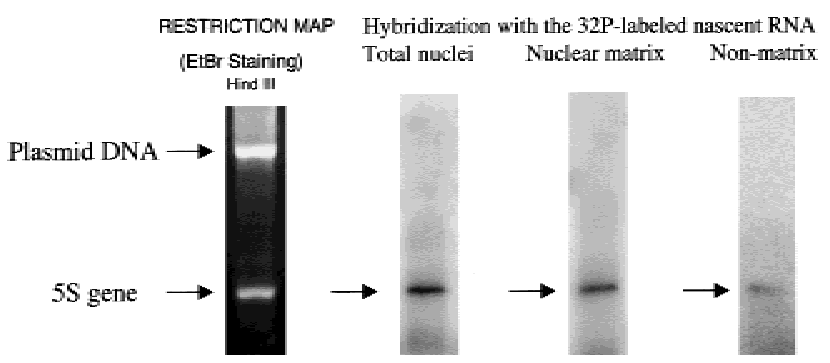

Figure 4. Association of the nascent 5S RNA with the nuclear matrix in gastrula embryos. Run-on transcription in the presence of $\left[{ }^{32} \mathrm{P}\right] \mathrm{UTP}$ was carried out on isolated nuclei from tailbud stage embryos, followed by the nuclear matrix isolation as described in Materials and Methods. Total, matrix-associated, and nonmatrix RNA was isolated and hybridized with the somatic $5 \mathrm{~S}$ gene immobilized on a Hybond $\mathrm{N}+$ membrane. 
Figure 5. Specification of the attachment sites in the somatic 5S RNA gene domain during development. (A) Restriction map of the somatic 5S gene unit. (B) Nuclei from gastrula embryos were treated with DNase I followed by $\mathrm{NaCl}$ extraction and the DNA remaining attached to the matrix was purified and radio labelled to probe different regions of the somatic 5S unit separated on agarose gel $(a-d)$. Alternately, the agarose-embedded nuclei were directly digested at physiological salt concentration with DNase I (Materials and Methods). The nucleoskeleton was separated from cleaved-off DNA by DNA electrophoresis, and the nucleoskeleton-associated DNA was isolated and used as probe (e). A HindIII somatic 5S insert first purified from a recombinant plasmid was further cut with AvaII and BanII to produce the map shown in $B$. The fragments were separated on agarose gel $(a$, ethidium bromide staining), and further probed with total DNA $(b)$, or with the nuclear matrix DNA from pre-MBT (2000-cell stage) embryos $(c)$ or post-MBT (stage 10) embryos $(d)$, as well as with the nuclear skeleton DNA from the stage 10 embryos $(e)$.
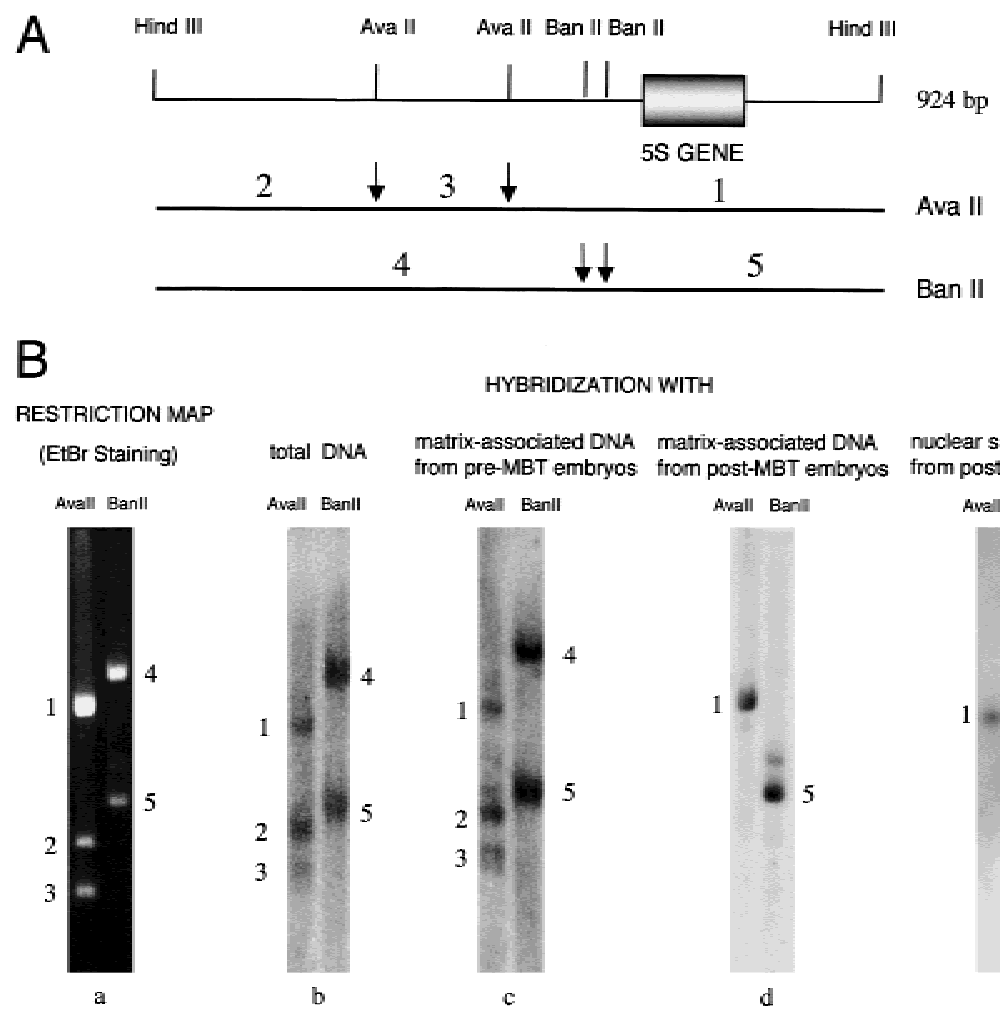

HYBRIDIZATION WITH

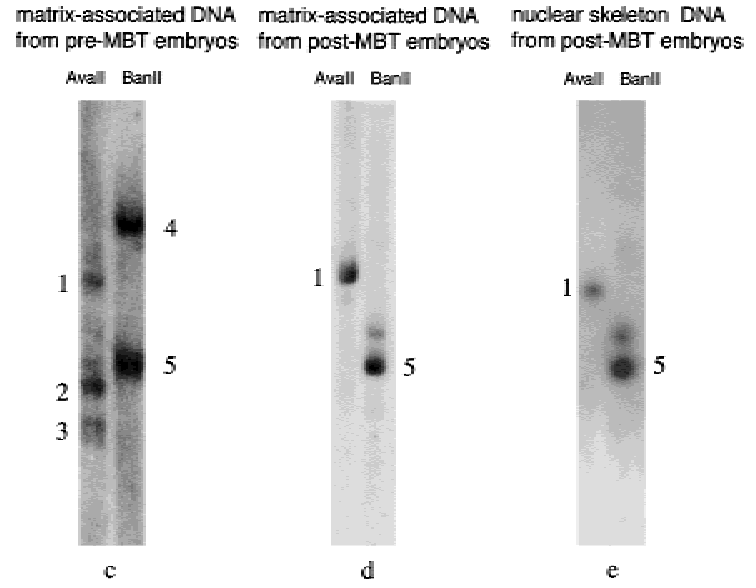

nuclear matrix fraction was also detected in the nucleoskeleton fraction (Fig. 5B).

As the nuclear skeleton/matrix fraction is enriched in active 5 S units (Fig. 4), we reasoned that the DNase I footprint of this specific fraction may reveal the organization of the 5 S unit. Nuclei were treated with DNase I as for a standard genomic footprint. This treatment also removes the DNA loop extending from the matrix (Fig. 6A). The nuclear matrix was isolated after DNase I treatment and the DNA remaining attached to the matrix analyzed by LM-PCR. This experimental scheme should reveal both a high-resolution map of the nuclear matrix site and detect the genomic footprint of the DNA domains anchored to the matrix. The results of this analysis, performed on pre- and post-MBT embryos, are shown in Figure 6, B and C.

In pre-MBT embryos, we found no clear signs of a transcriptionally determined domain on the nuclear matrixassociated DNA. Borders of a protected region on the matrix were not detected, as expected considering the nonspecific nature of the matrix attachment at this stage (Fig. 5). Some hypersensitive sites were present, as observed for the footprint of the total nuclear DNA fraction (Fig. 3), but the analysis failed to reveal large regions of protection in the coding strand. A region of partial protection at +80 to +90 of the noncoding strand (Fig. 6C, pre-MBT) could suggest abortive interactions of TFIIIA with this region before MBT (see below).

Entirely different results were observed for post-MBT embryos. Strong hypersensitive sites were observed at the borders of a protected region starting at $-42 \mathrm{bp}$ from the transcription start site and ending at $+126 \mathrm{bp}$. The almost total absence of bands $5^{\prime}$ and $3^{\prime}$ of these borders indicated that the DNA beyond was digested out from the matrix by DNase I, and that the LM-PCR method coupled to the nuclear matrix fraction permitted to define the two borders of the $5 \mathrm{~S}$ domain that were anchored to the nuclear matrix. The cluster of hypersensitive sites at the $3^{\prime}$ border overlaps the transcription termination region.

Inside the domain anchored to the matrix, the DNase I footprint revealed a reproducible organization on the promoter region. On the coding strand (Fig. 6B), a cluster of strong hypersensitive sites is present around position 50 , which is the border of the internal control region, and is followed by a region of protection extending to nucleotide 110 . On the noncoding strand, protection is observed from +80 to +90 . These regions of protection have been described previously as essential for promoter activity both by mutation analysis and studies on reconstituted transcription complexes. In the Xenopus laevis somatic $5 \mathrm{~S}$ gene, mutation analyses have identified nucleotides +50 to +60 (box A) and +80 to +90 (box C) as the main promoter (Pieler et al. 1985b, 1987). The binding of TFIIIA to $5 \mathrm{~S}$ genes was identified in a protected region from +45 to +98 in $X$. borealis (Engelke et al. 1980; Sakonju et al. 1981; Rhodes 1985). The +80 to +90 element of the noncoding strand is the strongest and main determinant for the binding of TFIIIA, through its first three zinc fingers (Fairall and Rhodes 1992; Liao et al. 1992). Box A is further required for the interaction of the 5S domain with TFIIIC (Lassar et al. 1983; Pieler et al. 1987). An additional region is protected on the noncoding strand, which overlaps the $5^{\prime}$ flanking region, at -42 
A

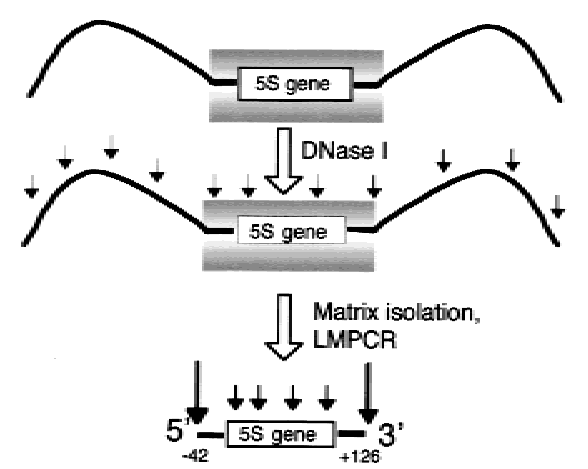

B

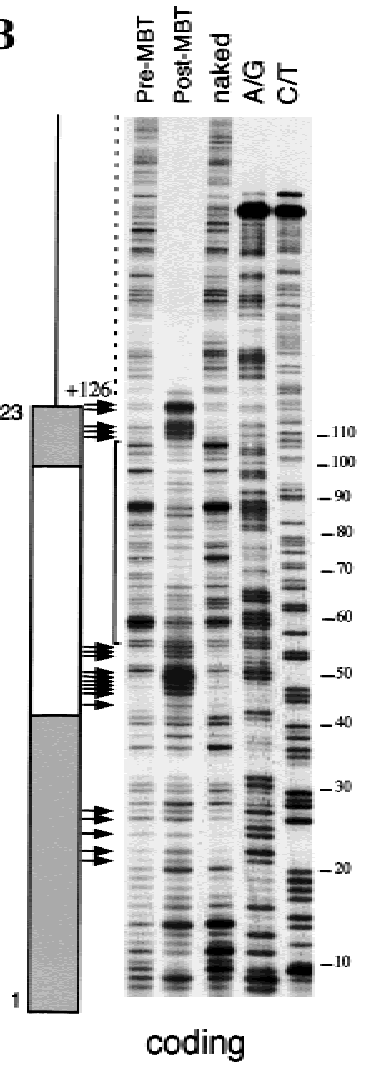

C
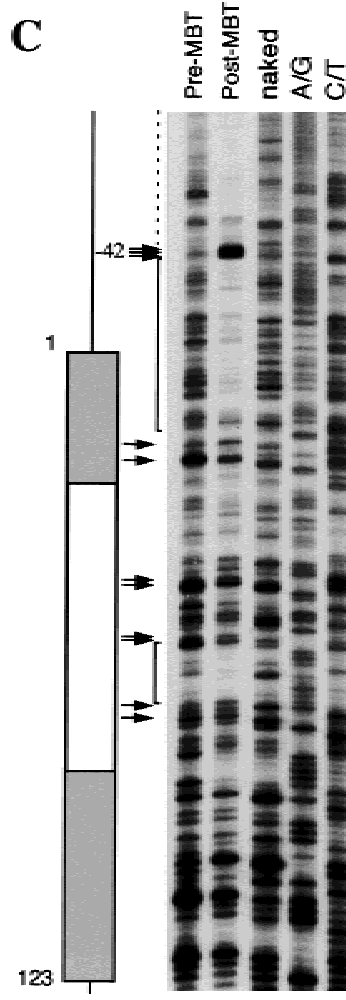

\section{non-coding}

Figure 6. Nuclear matrix purification coupled to LM-PCR on DNase I treated nuclei reveals a specific organization on the somatic 5S DNA in gastrula embryos. (A) Scheme of the procedure used. Nuclei from gastrula embryos were treated by DNase I and the DNA remaining attached to the nuclear matrix was isolated. The genomic footprinting was further analyzed by LMPCR as described in Material and Methods. (B) DNase I genomic footprint detected in the coding strand; $(C)$ footprint in the noncoding strand. The map of the somatic $5 \mathrm{~S}$ gene is shown with the internal control element $(+45$ to +98 , white box) as revealed by mutation analysis of the $X$. laevis gene or DNase I digestion of the TFIIIA $X$. borealis 5S DNA complex (Engelke et al. 1980; Sakonju et al. 1981; Pieler et al. 1985a,b, 1987). Pre-MBT and post-MBT refer to the DNase I genomic footprint from 2000-cell stage and stage 10 embryos, respectively, and naked DNA is the DNase I treatment of naked DNA. A/G and C/T are sequencing reactions. Arrows mark hypersensitive sites reproducibly observed in post-MBT embryos. Broken lines refer to DNA regions absent in the nuclear matrix of post-MBT embryos. Solid lines indicate regions where DNase I protections were detected.

to +26 (Fig. 6C). This region was detected previously in a genomic footprint of the Xenopus somatic 5S gene in erythrocyte nuclei (Chipev and Wolffe 1992), as well as in a $5 \mathrm{~S}$ transcription complex reconstituted in vitro (Wolffe and Morse 1990). We conclude that the somatic 5S domain specifically attached to the matrix in postMBT embryos contains the hallmarks of the interactions of the $5 \mathrm{~S}$ promoter with its known transcription factors.

Although not specifically analyzed here, nucleosome assembly might also contribute to the chromatin organization detected post-MBT. Ternary complexes of TFIIIA, naked DNA, and histone octamer have been found to be different between $X$. borealis and X. laevis $5 \mathrm{~S}$ genes (Rhodes 1985; Gottesfeld 1987; Lee et al. 1993; Howe et al. 1998). However, for both genes assembled with histones and TFIIIA, the contact of TFIIIA with the DNA between +80 and +90 of the noncoding strand is crucial to maintain, and was protected in vivo (Fig. $6 \mathrm{C}$ ). The TFIIIA binding to the octamer $5 \mathrm{~S}$ gene was shown to occur mainly between +62 and +95 (Lee et al. 1993). The cluster of hypersensitive sites centred at position $50(+45$ to +54 ) in the coding strand (Fig. $6 \mathrm{~B}$ ) was not observed previously in complexes between naked DNA and purified TFIIIA. It overlaps one promoter element (box A) involved in the bending of the internal promoter (Brown et al. 1996).

From this study, we conclude that in embryos engaged in somatic $5 \mathrm{~S}$ transcription only a subset of the $5 \mathrm{~S}$ domains appeared programmed for transcription, and that this subset can be identified by the isolation of the genomic fraction attached to the nuclear matrix. This subpopulation was not detected in pre-MBT embryos, except for partial protection over the strongest TFIIIA binding site, box C, which suggests abortive interactions of this region with the trans-activator during this stage.

\section{Discussion}

\section{Specification of chromatin domains during development}

In recent years, the organization of the nucleus has been shown more structurally fixed than previously thought. The attachment of chromosomal domains to the nuclear matrix is one level of organization that appears related to both genome organization and to the regulation of gene expression. We show here that the matrix binding is dynamic during embryonic development and that it might fractionate the genome into active and inactive domains.

During early development in Xenopus, four gene domains, rDNA, c-myc, keratin, and the somatic 5S gene, which are transcriptionally silent during this period, did not display specific attachment sites to the nuclear matrix. This was in contrast to the situation after the MBT when transcription resumed in the embryo for rDNA, c-myc, and the somatic $5 \mathrm{~S}$ gene, and when specific matrix attachment sites for the three gene domains could be identified. The keratin domain that is activated only in adult tadpoles just before metamorphosis did not exhibit a detectable rearrangement in the post-MBT embryos 
whereas a DNA domain starting $7 \mathrm{~kb}$ upstream of the keratin promoter appears to be specified in transcriptionally active keratinocytes.

The pattern observed before MBT may formally reflect the pleiotropic binding of multiple sites within the same gene domain. However, the apparently random organization observed for each of the domains analyzed does not argue in favor of a specificity of the attachment sites before MBT. In addition, in pre-MBT embryos, different methods for nuclear matrix preparation in the pre-MBT nuclei (LIS or $\mathrm{NaCl}$ extraction, heat stabilization, $\mathrm{Cu}^{2+}$ stabilization) all show a nonspecific association of the rDNA genes with the nucleoskeleton (data not shown). These results are also in agreement with the organization of the embryonic genome in pre-MBT embryos, when DNA replication occurs at a high rate in the absence of transcription. DNA replication is detected in the nuclear matrix fraction and occurs at close intervals, every 12-15 kb (Hyrien and Mechali 1993; Hyrien et al. 1995; Walter and Newport 1997), with no sequence specificity (Hyrien et al. 1995). It is therefore possible that during this period of transcriptional quiescence, the organization of the genome is mainly determined by the constraints linked to the rapid replication cycles.

In the rDNA domain, the matrix attachment is localized to the intergenic spacer, which is rich in promoter and enhancer elements. This same region was found attached to the matrix in gastrula embryos and in adult liver tissues. This region also corresponds to the region identified attached to the nuclear matrix in erythrocytes (Marilley and Gassend-Bonnet 1989), in HeLa cell nuclei (Keppel 1986), and in rat nucleoli (Stephanova et al. 1993). The developmental changes from apparently random to specific attachments of the rDNA domain to the matrix may be correlated to two other transitions that occur during the same developmental period. The first is an increase in the size of chromatin loops (BuongiornoNardelli et al. 1982) and the second is the specification of replication origins in the same region of the locus. After the MBT, DNA replication becomes site specific and is restricted to the intergenic spacer region (Hyrien et al. 1995). The same localization of the replication origin was found in Xenopus cells in culture (Bozzoni et al. 1981). The specification of the nuclear matrix attachment site at the onset of transcription in the embryo may help settle the replication origin. Alternatively, the stabilization of the rDNA chromatin domain, after the MBT, may permit this domain to be isolated for both transcription and replication.

The specification of the nuclear matrix attachment site was also observed with a single-copy gene transcribed by RNA polymerase II, c-myc, although this was more progressive than for the rDNA gene. During early development, no specific attachment was detected in the $5^{\prime}$ and $3^{\prime}$ flanking regions of this domain, but the coding sequence appeared in a region cleaved off by the DNase I treatment. In gastrula embryos, as well as in adult liver tissues, a 5' upstream region became predominantly attached to the matrix. The c-myc gene domain has been subjected to extensive studies at the chromatin level.
The upstream site I was a super-hypersensitive site located 2.5-kb upstream of the P2 promoter (Dyson et al. 1985 ) in proliferating cells expressing c-myc. In differentiating cells, when $\mathrm{c}-m y c$ transcription is repressed, the loss of several DNase I hypersensitive sites occurred, except for this upstream site. We found a major hypersensitive DNase I site in the same Xenopus c-myc region in proliferating Xenopus A6 cells in culture (Prioleau et al. 1995). The exclusion of the coding sequence from the nuclear matrix in transcriptionally quiescent embryos may indicate a first step in the organization of this domain before active transcription. This event would not be discerned in the multiple copy rDNA domain if the first organization step did not concern all the rDNA copies.

Genomic footprinting associated with nuclear matrix isolation permits chromatin hypersensitive sites and the boundaries of the $5 S$ somatic gene to be revealed in vivo

Although the nuclear matrix is not yet fully defined at the molecular level, it is clear that the isolation of the matrix reveals changes in the organization of the nucleus that are highly relevant to $5 \mathrm{~S}$ transcription regulation during development. It also unveils transcription-dependent chromatin footprints that could not be obtained without the nuclear matrix enrichment procedure. The transcription factor TFIIIA is the major activator regulating transcription of $5 \mathrm{~S}$ genes during Xenopus development (Wolffe 1994). The TFIIIA-5S complex has been extensively analyzed using purified TFIIIA and $X$. borealis DNA and has allowed the precise definition of DNase I accessibility to this complex (Engelke et al. 1980; Sakonju et al. 1981; Pieler et al. 1987; Fairall and Rhodes 1992). The complex with the X. laevis somatic 5S DNA had similar properties (Sakonju et al. 1981; Pieler et al. 1987; Wolffe and Morse 1990; Chipev and Wolffe 1992). The interaction of TFIIIA with reconstituted nucleosomes containing somatic 5S DNA also helped to define the contribution of histone assembly and nucleosome positioning (Rhodes 1985; Lee et al. 1993; Panetta et al. 1998). The chromatin organization of this gene in vivo is not so well documented except for nuclei from erythrocytes, which are transcriptionally quiescent. In this case, the somatic $5 \mathrm{~S}$ gene appears relatively accessible to nucleases, with some protection, occurring both in the internal promoter and in the 5' flanking region (Chipev and Wolffe 1992).

In the study of the oocyte type $5 \mathrm{~S}$ gene that expresses the oocyte 5S RNA at a high rate, no sign of the expected TFIIIA footprint was detected on the internal promoter (Engelke et al. 1980). Similarly, we were unable to detect a clear organization of the transcriptionally active somatic $5 \mathrm{~S}$ chromatin in post-MBT embryos. However, purification of the nuclear matrix coupled to LM-PCR footprinting allowed a specific chromatin organization to be selectively revealed. DNase I treatment was performed before nuclear matrix purification. This allowed a DNase I footprint to be obtained, as well as eliminating 
chromatin domains not anchored to the matrix. We observed that the $5 \mathrm{~S}$ gene domain is anchored to the matrix with two specific borders flanking the 5S transcription unit. These two borders are demarcated by two clusters of strong hypersensitive sites with the DNA beyond outwith the matrix. These borders were not observed when bulk chromatin was analyzed.

The chromatin organization of the 5S domain itself shows distinct regions of protection in the coding and the noncoding strand, both characteristic of TFIIIA binding to boxes A and C (Sakonju et al. 1981; Pieler et al. 1985a, 1987; Rhodes 1985). An additional large region protected in the noncoding strand $(-42$ to +26$)$ overlaps the transcription initiation site and was previously found necessary for transcription of the $5 \mathrm{~S}$ unit by increasing the recruitment of TFIIIB and TFIIIC (Wormington et al. 1981; Wolffe and Morse 1990). We did not detect a clear positioning of a nucleosome in the $5^{\prime}$ region of the $5 \mathrm{~S}$ unit. However, the in vivo genomic footprint detected here may reflect an organization more complex than in reconstituted nucleosomes in vitro. The cluster of strong hypersensitive sites at the $5^{\prime}$ border of the internal control element $(+45$ to +54$)$ was not observed previously in vitro and may be a specific feature of the active chromatin domain in vivo. It is located partially overlapping box $\mathrm{A}$, which is required for bending the internal promoter (Brown et al. 1996) and for transcriptional activation (Pieler et al. 1987). Although a defined nucleosome positioning could not be detected for the $X$. laevis somatic gene (Chipev and Wolffe 1992; Howe et al. 1998; Sera and Wolffe 1998), this site may correspond to a loose binding of the DNA at the border of box A, as suggested for the $X$. borealis gene (Rhodes 1985; Panetta et al. 1998), and therefore an increased DNase I sensitivity.

\section{Nuclear matrix anchorage and gene expression during development}

Before MBT, nuclear matrix anchorage appears to be random. Specific chromatin organization is not detected either in the bulk chromatin or in the nuclear matrix attached domains. In pre-MBT embryos, the partial protection of the strongest TFIIIA binding site for the somatic $5 S$ gene (box C) confirms that transactivators can access their DNA-binding sequences but that this is not sufficient to recruit the basal transcription machinery (Prioleau et al. 1995). Attachment to the nuclear matrix in post-MBT embryos may help to stabilize an active transcription complex.

One essential function of domain boundaries in regulating gene expression is to permit specific genes to be relatively independent of the surrounding chromosomal environment. In this way, stable transcription complexes can be assembled that are less prone to undesirable interactions. Insulator elements, LCR (locus control region) elements, or specific sequestration of chromatin domains, can contribute to the function of these boundaries. Matrix attachment sites have been found to define the boundaries of active chromatin domains including the chicken lysozyme gene (Loc and Stratling 1988), the rDNA in Xenopus erythrocytes (Marilley and GassendBonnet 1989), the human apolipoprotein gene (Levy-Wilson and Fortier 1989), and the Drosophila histone gene cluster (Mirkovitch et al. 1984).

Not all SAR/MAR elements function as insulators. However, the ability of SAR/MARs to confer stable and position-independent transcription to genes randomly integrated into the genome (Grosveld et al. 1987; Stief et al. 1989; Phi et al. 1990) strongly suggests that the SAR/ MARs may act as insulators in vivo. The MAR elements in the IgH locus are also crucial for the activation of a distal promoter independent of the chromosomal context (Forrester et al. 1994). The specification of the nuclear matrix attachment region reported here may contribute as well to the establishment of stable programs of transcription and cell lineages in the embryo.

The mechanism by which specification of the matrix attachment site is controlled is still unknown. Proteins that bind to the MARs could displace $\mathrm{H} 1$ and derepress chromatin (Zhao et al. 1993), which is in agreement with the dominant role of histone $\mathrm{H} 1$ in regulating the $5 \mathrm{~S}$ gene expression during early development (Bouvet et al. 1994; Kandolf 1994). Alternatively, MARs could cooperate with the enhancers to extend chromatin accessibility (Jenuwein et al. 1997), or recruit specific remodeling protein complexes at the promoter regions (Reyes et al. 1997). Specification can also be achieved indirectly by tethering proteins involved in transcription in large factories attached to the nucleoskeleton (Jackson et al. 1993). In this case, the specificity of the attachment of DNA domains to the matrix would be through recruitment by transcription factors and not by the matrix it self. Whatever the mechanisms involved, this specification might be an essential step in the determination of active and stable transcription complexes independent of the chromosomal context.

\section{Materials and methods}

Purification of nuclei and nuclear matrices

Nuclei were purified from Xenopus embryos (Gorski et al. 1986) and from Xenopus liver (Marilley and Gassend-Bonnet 1989). Nuclear matrices were prepared by treatment of the isolated nuclei with DNase I or restriction endonucleases followed by extraction with either LIS or $2 \mathrm{M} \mathrm{NaCl}$ essentially as described (Gasser and Vassetzky 1998).

In the LIS method, digestion buffer $(100 \mathrm{~mm} \mathrm{NaCl}, 25 \mathrm{~mm}$ $\mathrm{KCl}, 10 \mathrm{~mm}$ Tris- $\mathrm{HCl}$ at $\mathrm{pH} 7.5,0.25 \mathrm{~mm}$ spermidine, $1 \mathrm{~mm}$ $\mathrm{CaCl}_{2}$ ) was added to $10^{5}$ nuclei to a final volume of $400 \mu \mathrm{l}$. The nuclei were digested with $100 \mu \mathrm{g} / \mathrm{ml}$ DNase I for $3 \mathrm{hr}$ at $4^{\circ} \mathrm{C}$. The digestion was followed by a stabilization step, the addition of $\mathrm{CuCl}_{2}$ to a final concentration of $1 \mathrm{~mm}$, and incubation for 10 min at $4^{\circ} \mathrm{C}$. The nuclei were then extracted with five volumes of LIS extraction buffer containing $10 \mathrm{~mm}$ Tris- $\mathrm{HCl}$ at $\mathrm{pH} 7.5$, $0.25 \mathrm{~mm}$ spermidine, $2 \mathrm{~mm}$ EDTA-KOH at $\mathrm{pH} 7.5,0.1 \%$ Digitonin, and $25 \mathrm{~mm}$ LIS for $5 \mathrm{~min}$ at room temperature. The histone-depleted nuclear matrices were recovered by centrifugation and the nuclear matrix pellet was washed three times in a washing buffer containing $20 \mathrm{~mm}$ Tris- $\mathrm{HCl}$ at $\mathrm{pH} 7.5,0.25 \mathrm{~mm}$ spermidine, $0.05 \mathrm{~mm}$ spermine, $100 \mathrm{~mm} \mathrm{NaCl}$, and $0.1 \%$ Digi- 
tonin. The size range of the nuclear matrix attached DNA was 400-1500 bp.

In the $\mathrm{NaCl}$ method, $10^{5}$ nuclei were digested with $100 \mu \mathrm{g} / \mathrm{ml}$ DNase I in the digestion buffer as described above and stabilized by addition of $\mathrm{CuCl}_{2}$. The nuclei were then extracted by addition of one volume of a buffer containing $4 \mathrm{M} \mathrm{NaCl}, 20 \mathrm{~mm}$ EDTA, and $40 \mathrm{~mm}$ Tris- $\mathrm{HCl}$ at $\mathrm{pH}$ 7.5. The resulting nuclear matrices were removed by centrifugation and washed three times with $20 \mathrm{~mm}$ Tris- $\mathrm{HCl}$ at $\mathrm{pH} 7.5,2 \mathrm{M} \mathrm{NaCl}, 10 \mathrm{~mm}$ EDTA. The size range of the nuclear matrix-attached DNA was 200$800 \mathrm{bp}$.

Nuclear skeletons were prepared as decribed elsewhere (Jackson and Cook 1985). Embryonic nuclei $\left(10^{5}\right)$ were embedded in 1 volume of $2 \%$ low-melting agarose. The agarose blocks were washed in PBS and then digested in the digestion buffer with $100 \mu \mathrm{g} / \mathrm{ml}$ DNase I for $3 \mathrm{hr}$ at $4^{\circ} \mathrm{C}$. The nuclear skeletons were separated from the cleaved-off DNA loops by agarose gel electrophoresis performed on the agarode beads.

Nuclear matrices/skeletons were digested with proteinase K and extracted with phenol-chloroform. The DNA associated with the nuclear matrix/skeleton was treated with RNase A and used as a probe for hybridization or as a substrate for LMPCR.

\section{Run-on transcription}

Run-on transcription was carried out essentially as described in (Verheggen et al. 1998). The isolated nuclei of the tailbud stage embryos were permeabilized in $20 \mathrm{~mm}$ Tris- $\mathrm{HCl}$ at pH 7.4, $5 \mathrm{~mm}$ $\mathrm{MgCl}_{2}, 0.5 \mathrm{~mm}$ EGTA, $0.05 \%$ Triton-X 100, $5 \mu \mathrm{g} / \mathrm{ml}$ leupeptin, and $5 \mu \mathrm{g} / \mathrm{ml}$ pepstatin, washed in the same buffer without Triton-X 100, and incubated for $20 \mathrm{~min}$ at $23^{\circ} \mathrm{C}$ in a buffer containing $100 \mathrm{~mm} \mathrm{KCl}, 50 \mathrm{~mm}$ Tris- $\mathrm{HCl}$ at $\mathrm{pH} 7.4,5 \mathrm{~mm} \mathrm{MgCl}_{2}$, $0.5 \mathrm{~mm}$ EGTA, $25 \mu \mathrm{M}$ S-adenosyl L-methionine, $0.5 \mathrm{~mm}$ of ATP, CTP, GTP, $5 \mu \mathrm{Ci}\left[{ }^{32} \mathrm{P}\right] \mathrm{UTP}, 5 \mathrm{U} / \mathrm{ml}$ Rnasine, $5 \mu \mathrm{g} / \mathrm{ml}$ leupeptin, and $5 \mu \mathrm{g} / \mathrm{ml}$ pepstatin. The incubation was followed by the nuclear matrix isolation by the $\mathrm{NaCl}$ extraction. Total, matrixassociated, and nonmatrix RNA was purified and hybridized with the somatic $5 \mathrm{~S}$ gene immobilized on a Hybond $\mathrm{N}+$ membrane.

\section{$L M-P C R$}

LM-PCR was carried out essentially by the method of (Mueller and Wold 1989). Initial extension was with Vent (exo-) DNA polymerase (New England Biolabs) and amplification/labeling was with Gold Star DNA polymerase (Eurogentec). 5' primer labeling was with T4 polynucleotide kinase (Life Technologies) following manufacturers instructions. The primers used were: S1 (-96 to -78) 5'-GCTGGGGTTTTTTATCTTG-3'; S2 (-31 to -7) 5' -CAAGAGGAGGAAAAGTCAGCCTT-3'; S3 (-21 to +6) 5'-GGAAAAGTCAGCCTTGTGTTCGCCTAC-3'; S4 (195 to 178) 5'-CTAGCTGTCTGGCTGTTG-3'; S5 (157 to 138) 5'AGACTGCCCCCTGCTGCTCAGA-3'; S6 (150 to 125) 5'CCCCTGCTGCTCAGAAGGGCAAAGT-3'. The initial extension reaction was initiated with $250 \mathrm{ng}$ of DNA. Annealing temperatures used were $\mathrm{S} 1, \mathrm{~S} 4=50^{\circ} \mathrm{C} ; \mathrm{S} 2, \mathrm{~S} 5=65^{\circ} \mathrm{C}$, and $\mathrm{S} 3$, $\mathrm{S} 6=72^{\circ} \mathrm{C}$. Amplification was for 25 cycles. Labeling extension was for 5 cycles.

\section{Acknowledgments}

We thank T. Grange for his advice in the use of LMP-PCR genomic footprinting and C. Verheggen and D. Hernandez-Verdun for advice on the run-on transcription. We also thank G.
Cavalli, C. Jaulin, and S. Razin for comments, and S. Bocquet for expert help. This research has been supported by grants from the CNRS (ACCSV), the Association pour le Recherche Contre le Cancer, the Ligue Contre le Cancer, and a Human Capital and Mobility Fellowship to A.H.

The publication costs of this article were defrayed in part by payment of page charges. This article must therefore be hereby marked "advertisement" in accordance with 18 USC section 1734 solely to indicate this fact.

\section{References}

Almouzni, G. and A.P. Wolffe. 1995. Constraints on transcriptional activator function contribute to transcriptional quiescence during early Xenopus embryogenesis. EMBO $J$. 14: $1752-1765$.

Berezney, R. and D.S. Coffey. 1975. Nuclear protein matrix: Association with newly synthesized DNA. Science 189: 291-293.

Berezney, R., M.J. Mortillaro, H. Ma, X. Wei, and J. Samarabandu. 1995. The nuclear matrix: A structural milieu for genomic function. Int. Rev. Cytol. 162A: 1-65.

Bouvet, P., S. Dimitrov, and A.P. Wolffe. 1994. Specific regulation of Xenopus chromosomal 5S rRNA gene transcription in vivo by histone H1. Genes \& Dev. 8: 1147-1159.

Bozzoni, I., C.T. Baldari, F. Amaldi, and M. BuongiornoNardelli. 1981. Replication of ribosomal DNA in Xenopus laevis. Eur. J. Biochem. 118: 585-590.

Brown, M.L., G.P. Schroth, J.M. Gottesfeld, and D.P. BazettJones. 1996. Protein and DNA requirements for the transcription factor IIIA-induced distortion of the $5 \mathrm{~S}$ rRNA gene promoter. J. Mol. Biol. 262: 600-614.

Buongiorno-Nardelli, M., G. Micheli, M.T. Carri, and M. Marilley. 1982. A relationship between replicon size and supercoiled loop domains in the eukaryotic genome. Nature 298: $100-102$.

Chipev, C.C. and A.P. Wolffe. 1992. Chromosomal organization of $X$. laevis oocyte and somatic 5S rRNA genes in vivo. Mol. Cell. Biol. 12: 45-55.

Cockerill, P.N. and W.T. Garrard. 1986. Chromosomal loop anchorage of the kappa immunoglobulin gene occurs next to the enhancer in a region containing topoisomerase II sites. Cell 44: 273-282.

Dijkwel, P.A., J.P. Vaughn, and J.L. Hamlin. 1991. Mapping of replication initiation sites in mammalian genomes by twodimensional gel analysis: Stabilization and enrichment of replication intermediates by isolation on the nuclear matrix. Mol. Cell. Biol. 11: 3850-3859.

Dyson, P.J., T.D. Littlewood, A. Forster, and T.H. Rabbitts. 1985. Chromatin structure of transcriptionally active and inactive human c- myc alleles. EMBO J. 4: 2885-2891.

Engelke, D.R., S.Y. Ng, B.S. Shastry, and R.G. Roeder. 1980. Specific interaction of a purified transcription factor with an internal control region of 5S RNA genes. Cell 19: 717-728.

Fairall, L. and D. Rhodes. 1992. A new approach to the analysis of DNase I footprinting data and its application to the TFIIIA/5S DNA complex. Nucleic Acids Res. 20: 47274731.

Forrester, W.C., C. van Genderen, T. Jenuwein, and R. Grosschedl. 1994. Dependence of enhancer-mediated transcription of the immunoglobulin mu gene on nuclear matrix attachment regions. Science 265: 1221-1225.

Gasser, S.M. and U.K. Laemmli. 1986. Cohabitation of scaffold binding regions with upstream/enhancer elements of three developmentally regulated genes of D. melanogaster. Cell 46: $521-530$. 
Gasser, S.M. and Y.S. Vassetzky. 1998. Analysis of nuclear scaffold attachment regions. In Chromatin: A pratical approach (ed. H. Gould), pp. 111-124. Oxford University Press, Oxford, UK.

Gorski, K., M. Carneiro, and U. Schibier. 1986. Tissue-specific in vitro transcription from the mouse albumin promoter. Cell 47: 767-776.

Gottesfeld, J.M. 1987. DNA sequence-directed nucleosome reconstitution on 5S RNA genes of Xenopus laevis. Mol. Cell. Biol. 7: 1612-1622.

Grosveld, F., G.B. van Assendelft, D.R. Greaves, and G. Kollias. 1987. Position-independent, high-level expression of the human beta-globin gene in transgenic mice. Cell 51: 975 985.

Howe, L., T.A. Ranalli, C.D. Allis, and J. Ausio. 1998. Transcriptionally active Xenopus laevis somatic $5 \mathrm{~S}$ ribosomal RNA genes are packaged with hyperacetylated histone $\mathrm{H} 4$, whereas transcriptionally silent oocyte genes are not. J. Biol. Chem. 273: 20693-20696.

Hyrien, O. and M. Mechali. 1993. Chromosomal replication initiates and terminates at random sequences but at regular intervals in the ribosomal DNA of Xenopus early embryos. ЕМВО J. 12: 4511-4520.

Hyrien, O., C. Maric, and M. Mechali. 1995. Transition in specification of embryonic metazoan DNA replication origins Science 270: 994-997.

Jackson, D.A. 1997. Chromatin domains and nuclear compartments: Establishing sites of gene expression in eukaryotic nuclei. Mol. Biol. Rep. 24: 209-220.

Jackson, D.A. and P.R. Cook. 1985. Transcription occurs at a nucleoskeleton. EMBO J. 4: 919-925.

Jackson, D.A., A.B. Hassan, R.J. Errington, and P.R. Cook. 1993. Visualization of focal sites of transcription within human nuclei. EMBO J. 12: 1059-1065.

Jarman, A.P. and D.R. Higgs. 1988. Nuclear scaffold attachment sites in the human globin gene complexes. EMBO J. 7: 33373344.

Jenuwein, T., W.C. Forrester, L.A. Fernandez-Herrero, G. Laible, M. Dull, and R. Grosschedl. 1997. Extension of chromatin accessibility by nuclear matrix attachment regions. Nature 385: 269-272.

Kandolf, H. 1994. The H1A histone variant is an in vivo repressor of oocyte-type $5 \mathrm{~S}$ gene transcription in Xenopus laevis embryos. Proc. Nat1. Acad. Sci. 91: 7257-7261.

Keppel, F. 1986. Transcribed human ribosomal RNA genes are attached to the nuclear matrix. J. Mol. Biol. 187: 15-21.

King, M.W., J.M. Roberts, and R.N. Eisenman. 1986. Expression of the c-myc proto-oncogene during development of Xenopus laevis. Mol. Cell. Biol. 6: 4499-4508.

Laemmli, U.K., E. Kas, L. Poljak, and Y. Adachi. 1992. Scaffoldassociated regions: Cis-acting determinants of chromatin structural loops and functional domains. Curr. Opin. Genet. Dev. 2: 275-285.

Lassar, A.B., P.L. Martin, and R.G. Roeder. 1983. Transcription of class III genes: Formation of preinitiation complexes. Science 222: 740-748.

Lee, D.Y., J.J. Hayes, D. Pruss, and A.P. Wolffe. 1993. A positive role for histone acetylation in transcription factor access to nucleosomal DNA. Cell 72: 73-84.

Levy-Wilson, B. and C. Fortier. 1989. Tissue-specific undermethylation of DNA sequences at the $5^{\prime}$ end of the human apolipoprotein B gene. J. Biol. Chem. 264: 9891-9896.

Liao, X.B., K.R. Clemens, L. Tennant, P.E. Wright, and J.M. Gottesfeld. 1992. Specific interaction of the first three zinc fingers of TFIIIA with the internal control region of the Xenopus 5 S RNA gene. J. Mol. Biol. 223: 857-871.
Loc, P.V. and W.H. Stratling. 1988. The matrix attachment regions of the chicken lysozyme gene co-map with the boundaries of the chromatin domain. EMBO J. 7: 655-664.

Marilley, M. and G. Gassend-Bonnet. 1989. Supercoiled loop organization of genomic DNA: A close relationship between loop domains, expression units, and replicon organization in rDNA from Xenopus laevis. Exp. Cell. Res. 180: 475-489.

Mirkovitch, J., M.E. Mirault, and U.K. Laemmli. 1984. Organization of the higher-order chromatin loop: Specific DNA attachment sites on nuclear scaffold. Cell 39: 223-232.

Mueller, P.R. and B. Wold. 1989. In vivo footprinting of a muscle specific enhancer by ligation mediated PCR. Science 246: 780-786.

Newport, J. and M. Kirschner. 1982. A major developmental transition in early Xenopus embryos: II. Control of the onset of transcription. Cell 30: 687-696.

Nishikawa, A., K. Shimizu-Nishikawa, and L. Miller. 1992. Spatial, temporal, and hormonal regulation of epidermal keratin expression during development of the frog, Xenopus laevis. Dev. Biol. 151: 145-153.

Panetta, G., M. Buttinelli, A. Flaus, T.J. Richmond, and D. Rhodes. 1998. Differential nucleosome positioning on Xenopus oocyte and somatic 5 S RNA genes determines both TFIIIA and $\mathrm{H} 1$ binding: A mechanism for selective $\mathrm{H} 1$ repression. J. Mol. Biol. 282: 683-697.

Paulson, J.R. and U.K. Laemmli. 1977. The structure of histonedepleted metaphase chromosomes. Cell 12: 817-828.

Phi, V.L., K.J. Von, W. Ostertag, and W.H. Strätling. 1990. The chicken lysozyme 5' matrix attachment region increases transcription from a heterologous promoter in heterologous cells and dampens position effects on the expression of transfected genes. Mol. Cell. Biol. 10: 2302-2307.

Pieler, T. and O. Theunissen. 1993. TFIIIA: Nine fingers-three hands? Trends Biochem. Sci. 18: 226-230.

Pieler, T., B. Appel, S.L. Oei, H. Mentzel, and V.A. Erdmann. 1985a. Point mutational analysis of the Xenopus laevis 5S gene promoter. EMBO J. 4: 1847-1853.

Pieler, T., S.L. Oei, J. Hamm, U. Engelke, and V.A. Erdmann. 1985b. Functional domains of the Xenopus laevis 5S gene promoter. EMBO I. 4: 3751-3756.

Pieler, T., J. Hamm, and R.G. Roeder. 1987. The 5 S gene internal control region is composed of three distinct sequence elements, organized as two functional domains with variable spacing. Cell 48: 91-100.

Prioleau, M.N., J. Huet, A. Sentenac, and M. Mechali. 1994. Competition between chromatin and transcription complex assembly regulates gene expression during early development. Cell 77: 439-449.

Prioleau, M.N., R.S. Buckle, and M. Mechali. 1995. Programming of a repressed but committed chromatin structure during early development. EMBO J. 14: 5073-5084.

Reyes, J.C., C. Muchardt, and M. Yaniv. 1997. Components of the human SWI/SNF complex are enriched in active chromatin and are associated with the nuclear matrix. I. Cell Biol. 137: 263-274.

Rhodes, D. 1985. Structural analysis of a triple complex between the histone octamer, a Xenopus gene for 5S RNA and transcription factor IIIA. EMBO J. 4: 3473-3482.

Sakonju, S., D.D. Brown, D. Engelke, S.Y. Ng, B.S. Shastry, and R.G. Roeder. 1981. The binding of a transcription factor to deletion mutants of a 5S ribosomal RNA gene. Cell 23: 665669.

Scheuermann, R.H. and U. Chen. 1989. A developmental-specific factor binds to suppressor sites flanking the immunoglobulin heavy-chain enhancer. Genes \& Dev. 3: 1255-1266.

Sera, T. and A.P. Wolffe. 1998. Role of histone H1 as an archi- 
tectural determinant of chromatin structure and as a specific repressor of transcription on Xenopus oocyte 5S rRNA genes. Mol. Cell. Biol. 18: 3668-3680.

Shiokawa, K., Y. Misumi, and K. Yamana. 1981. Demonstration of rRNA synthesis in pre-gastrular embryos of Xenopus laevis. Dev. Growth Differ. 23: 579-587.

Stein, G.S., A.J. van Wijnen, J. Stein, J.B. Lian, and M. Montecino. 1995. Contributions of nuclear architecture to transcriptional control. Int. Rev. Cytol. 162A: 251-278.

Stephanova, E., R. Stancheva, and Z. Avramova. 1993. Binding of sequences from the $5^{\prime}$ - and $3^{\prime}$-nontranscribed spacers of the rat rDNA locus to the nucleolar matrix. Chromosoma 102: $287-295$.

Stief, A., D.M. Winter, W.H. Stratling, and A.E. Sippel. 1989. A nuclear DNA attachment element mediates elevated and position-independent gene activity. Nature 341: 343-345.

Taylor, M.V., M. Gusse, G.I. Evan, N. Dathan, and M. Mechali. 1986. Xenopus myc proto-oncogene during development: Expression as a stable maternal mRNA uncoupled from cell division. EMBO J. 5: 3563-3570.

Verheggen, C., S. Le Panse, G. Almouzni, and D. HernandezVerdun. 1998. Presence of pre-rRNAs before activation of polymerase I transcription in the building process of nucleoli during early development of Xenopus laevis. J. Cell Biol. 142: $1167-1180$.

Vermaak, D. and A.P. Wolffe. 1998. Chromatin and chromosomal controls in development. Dev. Genet. 22: 1-6.

Vogelstein, B., D.M. Pardoll, and D.S. Coffey. 1980. Supercoiled loops and eucaryotic DNA replication. Cell 22: 79-85.

Walter, J. and J.W. Newport. 1997. Regulation of replicon size in Xenopus egg extracts. Science 275: 993-995.

Warshawsky, D. and L. Miller. 1995. Tissue-specific in vivo protein-DNA interactions at the promoter region of the Xenopus $63 \mathrm{kDa}$ keratin gene during metamorphosis. Nucleic Acids Res. 23: 4502-4509.

. 1997. In vivo footprints are found in the Xenopus $63 \mathrm{kDa}$ keratin gene promoter prior to the appearance of mRNA. Gene 189: 209-212.

Wolffe, A.P. 1994. The role of transcription factors, chromatin structure and DNA replication in 5 S RNA gene regulation. J. Cell Sci. 107: 2055-2063.

Wolffe, A.P. and D.D. Brown. 1988. Developmental regulation of two 5S ribosomal RNA genes. Science 241: 1626-1632.

Wolffe, A.P. and R.H. Morse. 1990. The transcription complex of the Xenopus somatic $5 \mathrm{~S}$ RNA gene. A functional analysis of protein-DNA interactions outside of the internal control region. J. Biol. Chem. 265: 4592-4599.

Wormington, W.M., D.F. Bogenhagen, E. Jordan, and D.D. Brown. 1981. A quantitative assay for Xenopus 5S RNA gene transcription in vitro. Cell 24: 809-817.

Zhao, K., E. Kas, E. Gonzalez, and U.K. Laemmli. 1993. SARdependent mobilization of histone $\mathrm{H} 1$ by HMG-I/Y in vitro: HMG-I/Y is enriched in H1-depleted chromatin. EMBO $J$. 12: 3237-3247.

Zong, R.T. and R.H. Scheuermann. 1995. Mutually exclusive interaction of a novel matrix attachment region binding protein and the NF-muNR enhancer repressor. Implications for regulation of immunoglobulin heavy chain expression. $I$. Biol. Chem. 270: 24010-24018. 


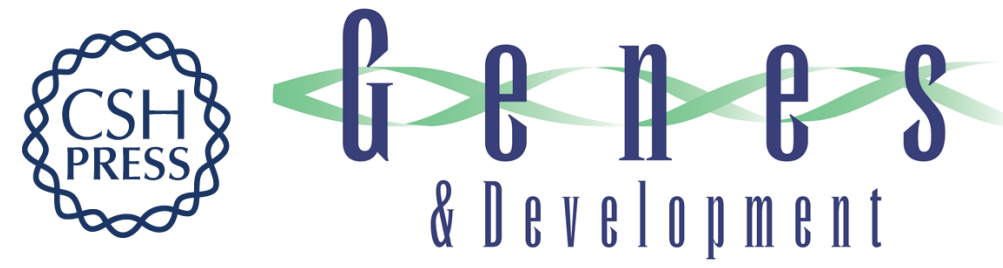

\section{Rearrangement of chromatin domains during development in Xenopus}

Yegor Vassetzky, Alan Hair and Marcel Méchali

Genes Dev. 2000, 14:

Access the most recent version at doi:10.1101/gad.14.12.1541

References This article cites 71 articles, 23 of which can be accessed free at: http://genesdev.cshlp.org/content/14/12/1541.full.html\#ref-list-1

License

Email Alerting

Receive free email alerts when new articles cite this article - sign up in the box at the top Service right corner of the article or click here.

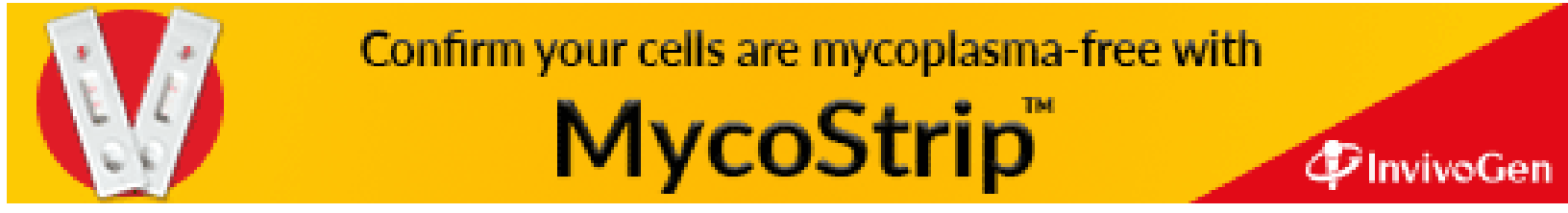

